\title{
Initial hyperinsulinemia and subsequent $\beta$-cell dysfunction is associated with elevated palmitate levels
}

\author{
Johan Staaf',2, Sarojini J.K.A. Ubhayasekera ${ }^{3}$, Ernest Sargsyan', Azazul Chowdhury', Hjalti Kristinsson ', Hannes Manell ${ }^{1,2}$, \\ Jonas Bergquist ${ }^{3}$, Anders Forslund ${ }^{2}$ and Peter Bergsten ${ }^{1}$
}

\begin{abstract}
BACKGROUND: The prevalence of obesity-related diabetes in childhood is increasing and circulating levels of nonesterified fatty acids may constitute a link. Here, the association between palmitate and insulin secretion was investigated in vivo and in vitro.
\end{abstract}

METHODS: Obese and lean children and adolescents $(n=80)$ were included. Palmitate was measured at fasting; insulin and glucose during an oral glucose tolerance test (OGTT). Human islets were cultured for 0 to $7 \mathrm{~d}$ in presence of $0.5 \mathrm{mmol} / \mathrm{l} \mathrm{pal-}$ mitate. Glucose-stimulated insulin secretion (GSIS), insulin content and apoptosis were measured.

RESULTS: Obese subjects had fasting palmitate levels between 0.10 and $0.33 \mathrm{mmol} / \mathrm{l}$, with higher average levels compared to lean subjects. While obese children with elevated palmitate $(>0.20 \mathrm{mmol} / \mathrm{l})$ had accentuated insulin levels during OGTT, obese adolescents with high palmitate had delayed first-phase insulin response. In human islets exposed to palmitate for $2 \mathrm{~d}$ GSIS was twofold enhanced, but after $7 \mathrm{~d}$ attenuated. Intracellular insulin content decreased time-dependently in islets cultured in the presence of palmitate and cleaved caspase 3 increased.

CONCLUSION: The rapid accentuated and delayed insulin secretory responses observed in obese children and adolescents, respectively, with high palmitate levels may reflect changes in islet secretory activity and integrity induced by extended exposure to the fatty acid.

O besity in children is associated with type 2 diabetes mellitus (T2DM) and the prevalence of both childhood obesity and T2DM have increased (1). Obesity commonly precedes manifest T2DM and affects both insulin-secreting $\beta$-cells and insulin-target tissue (2). Indeed, approximately $85 \%$ of children with T2DM are overweight or obese (3). Children with obesity consequently have increased risk of developing metabolic complications already in their youth (4), which makes the obesity epidemic a serious threat to global health.

Elevated concentrations of circulating nonesterified fatty acids (NEFAs) have been implicated as a factor connecting obesity with T2DM(5). High NEFA concentrations are observed in both obese adults $(5,6)$ and children $(7)$ and have been associated with insulin secretion in vivo $(8,9)$. Among circulating NEFAs, the saturated fatty acid palmitate (C16:0) is one of the most abundant (10). Palmitate has previously been associated with both postprandial insulin secretion and insulin sensitivity in vivo (11) and extensively investigated in vitro in connection with decline in islet $\beta$-cell function and mass after prolonged exposure (12). Detrimental effects of chronic palmitate exposure include shifts in sphingolipid metabolism as well as initiation of oxidative stress, downregulation of glucokinase, and triggering of endoplasmic reticulum-stress response (13-18). In addition, palmitate contributes to inhibition of insulin processing, resulting in an increase in the proinsulin to insulin ratio (19). In contrast, when palmitate concentration is acutely increased, insulin secretion is stimulated $(20,21)$, where free fatty acid receptor 1 plays an important role (22).

Here, we investigated how elevated palmitate levels are related to the insulin secretory response to glucose in obese children and adolescents as well as in isolated human islets. The cross-sectional in vivo study was complemented by an in vitro approach, where effects of fixed palmitate concentrations were studied in a controlled, longitudinal setting. We hypothesized that insulin secretion is accentuated in obese children with high palmitate levels and later becomes impaired in obese adolescents.

\section{RESULTS}

Palmitate and Insulin Concentrations at Fasting

Fasting palmitate levels showed an approximate fourfold range in the whole study population and were normally distributed with a mean of $0.19 \mathrm{mmol} / \mathrm{l}$ (Figure 1a). Palmitate levels were higher in obese subjects (Figure 1b). Fasting palmitate was neither associated with pubertal stage (age) (Table 1) nor with gender (data not shown). Fasting insulin levels in obese subjects were approximately threefold higher compared to lean subjects (Table 1). Fasting insulin correlated with palmitate levels for the whole study population $(P<0.005)$ (Figure 1c). When analyzing the obese and 

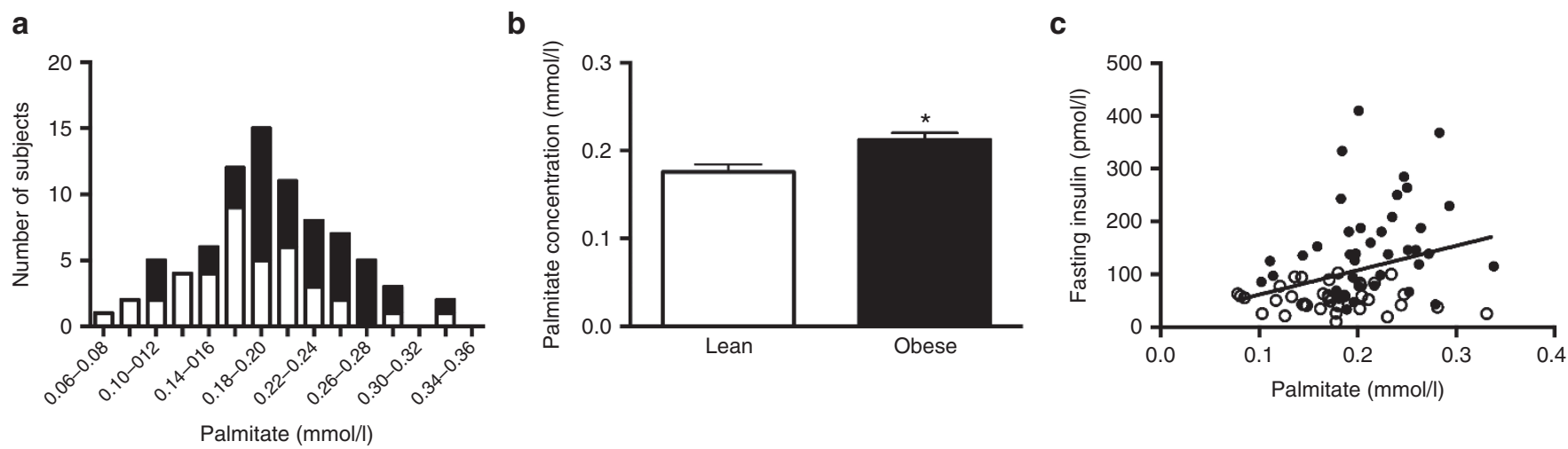

Figure 1. Palmitate levels in obese and lean subjects. Fasting palmitate concentrations in 40 obese (black bars and circles) and 40 lean (white bars and circles) children and adolescents showed as distribution (panel a), mean concentration \pm SEM (panel b), and correlation to fasting insulin (panel c). In panel $\mathbf{c}_{\text {; }} \mathrm{R}_{\text {spearman }}=0.335, P=0.0029$ for whole study population; $\mathrm{R}_{\text {spearman }}=0.275, P=0.0902$ for obese children and $\mathrm{R}_{\text {spearman }}=-0.0553, P=0.7416$ for lean children; regression line for whole study population shown in graph. ${ }^{*} P<0.05$ vs. lean subjects in panel $\mathbf{b}$.

Table 1. Fasting characteristics of study population

\begin{tabular}{|c|c|c|c|c|c|c|c|c|c|c|}
\hline & \multicolumn{3}{|c|}{ Lean subjects } & \multicolumn{7}{|c|}{ Obese subjects } \\
\hline & Total & $\begin{array}{l}\text { Prepubertal } \\
\text { children }\end{array}$ & $\begin{array}{c}\text { Pubertal } \\
\text { adolescents }\end{array}$ & Total & $\begin{array}{l}\text { Prepubertal } \\
\text { children }\end{array}$ & $\begin{array}{c}\text { Pubertal } \\
\text { adolescents }\end{array}$ & $\begin{array}{c}\text { Prepubertal } \\
\text { children low PA }\end{array}$ & $\begin{array}{c}\text { Pubertal } \\
\text { adolescents } \\
\text { low PA }\end{array}$ & $\begin{array}{c}\text { Prepubertal } \\
\text { children high } \\
\text { PA }\end{array}$ & $\begin{array}{c}\text { Pubertal } \\
\text { adolescents } \\
\text { high PA }\end{array}$ \\
\hline $\begin{array}{l}\text { Number of } \\
\text { subjects }\end{array}$ & 40 & 19 & 21 & 40 & 20 & 20 & 10 & 10 & 10 & 10 \\
\hline Age & $\begin{array}{c}11.6 \pm 0.7 \\
(7-17)\end{array}$ & $\begin{array}{c}9.5 \pm 0.4 \\
(6-10)\end{array}$ & $\begin{array}{c}14.7 \pm 0.6 \\
(10-18)\end{array}$ & $\begin{array}{c}11.6 \pm 0.6 \\
(3-18)\end{array}$ & $\begin{array}{c}8.7 \pm 0.6 \\
(3-12)\end{array}$ & $\begin{array}{c}14.4 \pm 0.4 \\
(10-18)\end{array}$ & $7.3 \pm 0.8(3-12)$ & $\begin{array}{c}14.2 \pm 0.5 \\
(12-18)\end{array}$ & $\begin{array}{c}10.1 \pm 0.5 \\
(8-12)\end{array}$ & $\begin{array}{c}14.6 \pm 0.6 \\
(10-16)\end{array}$ \\
\hline Gender & $\begin{array}{l}19 \text { females } \\
21 \text { males }\end{array}$ & $\begin{array}{l}8 \text { females } \\
11 \text { males }\end{array}$ & $\begin{array}{l}11 \text { females } \\
10 \text { males }\end{array}$ & $\begin{array}{l}19 \text { females } \\
21 \text { males }\end{array}$ & $\begin{array}{l}10 \text { females } \\
10 \text { males }\end{array}$ & $\begin{array}{l}9 \text { females } \\
11 \text { males }\end{array}$ & $\begin{array}{l}6 \text { females } \\
4 \text { males }\end{array}$ & $\begin{array}{l}6 \text { females } \\
4 \text { males }\end{array}$ & $\begin{array}{l}4 \text { females } \\
6 \text { males }\end{array}$ & $\begin{array}{l}3 \text { females } \\
7 \text { males }\end{array}$ \\
\hline $\begin{array}{l}\text { Palmitate } \\
(\mathrm{mmol} / \mathrm{l})\end{array}$ & $\begin{array}{c}0.17 \pm 0.01 \\
(0.08-0.33)\end{array}$ & $\begin{array}{c}0.17 \pm 0.01 \\
(0.10-0.33)\end{array}$ & $\begin{array}{c}0.18 \pm 0.01 \\
(0.08-0.28)\end{array}$ & $\begin{array}{l}0.21 \pm 0.01 * \\
(0.10-0.34)\end{array}$ & $\begin{array}{l}0.22 \pm 0.01^{*} \\
(0.11-0.34)\end{array}$ & $\begin{array}{l}0.21 \pm 0.01^{*} \\
(0.10-0.29)\end{array}$ & $\begin{array}{l}0.18 \pm 0.01 \\
(0.11-0.20)\end{array}$ & $\begin{array}{c}0.16 \pm 0.01 \\
(0.10-0.20)\end{array}$ & $\begin{array}{l}0.25 \pm 0.01 * \\
(0.20-0.34)\end{array}$ & $\begin{array}{l}0.25 \pm 0.01^{*} \\
(0.22-0.29)\end{array}$ \\
\hline $\begin{array}{l}\text { Insulin } \\
\text { (pmol/l) }\end{array}$ & $\begin{array}{c}55 \pm 7 \\
(22-121)\end{array}$ & $\begin{array}{c}34 \pm 6 \\
(22-59)\end{array}$ & $\begin{array}{c}65 \pm 7(26- \\
121)\end{array}$ & $\begin{array}{l}154 \pm 14^{*} \\
(33-410)\end{array}$ & $\begin{array}{l}136 \pm 16^{*} \\
(33-285)\end{array}$ & $\begin{array}{l}173 \pm 23^{*} \\
(43-410)\end{array}$ & $\begin{array}{l}92 \pm 16 * \\
(33-181)\end{array}$ & $\begin{array}{l}186 \pm 37^{*} \\
(85-410)\end{array}$ & $\begin{array}{l}180 \pm 21^{*} \\
(78-285)\end{array}$ & $\begin{array}{l}161 \pm 30 * \\
(43-368)\end{array}$ \\
\hline $\begin{array}{l}\text { Glucose } \\
\text { (mmol/l) }\end{array}$ & $\begin{array}{l}5.4 \pm 0.1 \\
(4.6-5.9)\end{array}$ & $\begin{array}{c}5.3 \pm 0.1 \\
(4.6-5.9)\end{array}$ & $\begin{array}{l}5.4 \pm 0.2 \\
(4.7-5.9)\end{array}$ & $\begin{array}{l}5.0 \pm 0.1 \\
(4.4-5.9)\end{array}$ & $\begin{array}{c}5.1 \pm 0.1 \\
(4.6-5.9)\end{array}$ & $\begin{array}{l}4.9 \pm 0.1 \\
(4.4-5.4)\end{array}$ & $\begin{array}{l}5.1 \pm 0.1 \\
(4.6-5.7)\end{array}$ & $\begin{array}{l}4.9 \pm 0.1 \\
(4.4-5.4)\end{array}$ & $\begin{array}{l}5.1 \pm 0.1 \\
(4.7-5.9)\end{array}$ & $\begin{array}{l}4.9 \pm 0.1 \\
(4.4-5.4)\end{array}$ \\
\hline
\end{tabular}

Results are means \pm SEM and range in parenthesis. ${ }^{*} P<0.05 \mathrm{vs}$. lean subjects. PA, palmitate.

lean sub-populations separately, lean subjects showed no correlation. In the obese subjects, a positive relationship was observed $(P=0.09)$. Fasting glucose levels were not different between the groups, however (Table 1 ).

To further study the associations between fasting palmitate and insulin concentrations in children and adolescents with obesity separately, the obese subjects were divided into two groups, "low palmitate" and "high palmitate", with the median $0.20 \mathrm{mmol} / \mathrm{l}$ as devisor. The low and high palmitate groups were further divided into children and adolescents based on sex hormone levels. In obese children with high palmitate levels, fasting insulin was $180 \pm 21 \mathrm{pmol} / \mathrm{l}$, which was twofold higher than levels in obese children with low palmitate levels and fivefold higher than levels in lean children (Table 1). Obese adolescents with high palmitate levels had fasting insulin concentration of $161 \pm 30 \mathrm{pmol} / \mathrm{l}$, which was not different from fasting insulin concentration in obese adolescents with low palmitate levels but 2.5-fold higher than in lean adolescents (Table 1).
Insulin Secretion During Oral Glucose Tolerance Test

In obese children with high palmitate, insulin increased sharply with a peak after $30 \mathrm{~min}$ with a concentration of $1,597 \pm 277 \mathrm{pmol} / 1$ (Figure 2a). Insulin levels subsequently declined but remained higher than in lean children throughout the oral glucose tolerance test (OGTT) (Figure 2b). In obese children with low palmitate, the insulin levels also peaked after $30 \mathrm{~min}$ but merely at $586 \pm 91$ $\mathrm{pmol} / \mathrm{l}$, which was similar to lean children. In fact, insulin levels during OGTT of obese children with low palmitate levels were, apart from fasting levels, only significantly elevated compared to lean children at 90 and $120 \mathrm{~min}$ (Figure 2b). Insulin levels during the initial $30 \mathrm{~min}$ of the OGTT were further examined. The most prominent change in secretory rate was observed in obese children with high palmitate levels between 5 and $10 \mathrm{~min}$ of the OGTT, when insulin concentration rose with $113 \mathrm{pmol} / \mathrm{l} / \mathrm{min}$ on average, with a max-value of $204 \mathrm{pmol} / \mathrm{l} / \mathrm{min}$ (female, $8 \mathrm{y}$ old) (Figure 2c). Finally, insulin levels were related to the secretion rate at fasting and fold increase in insulin secretion over basal secretion was calculated. In lean children, an 11-fold rise in insulin 


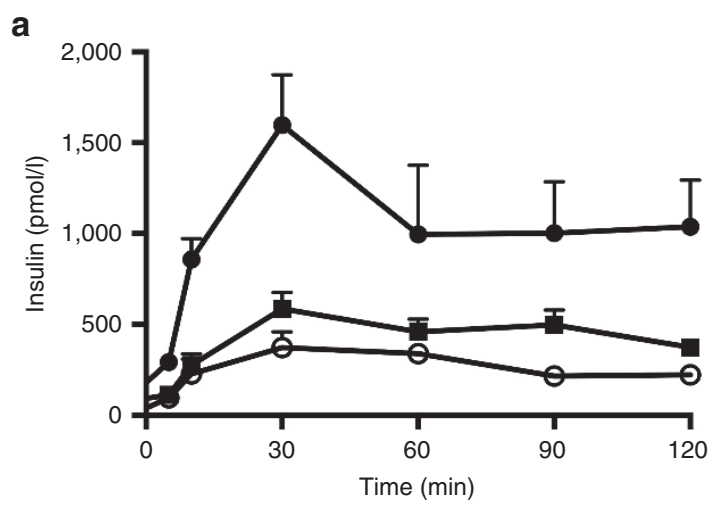

C

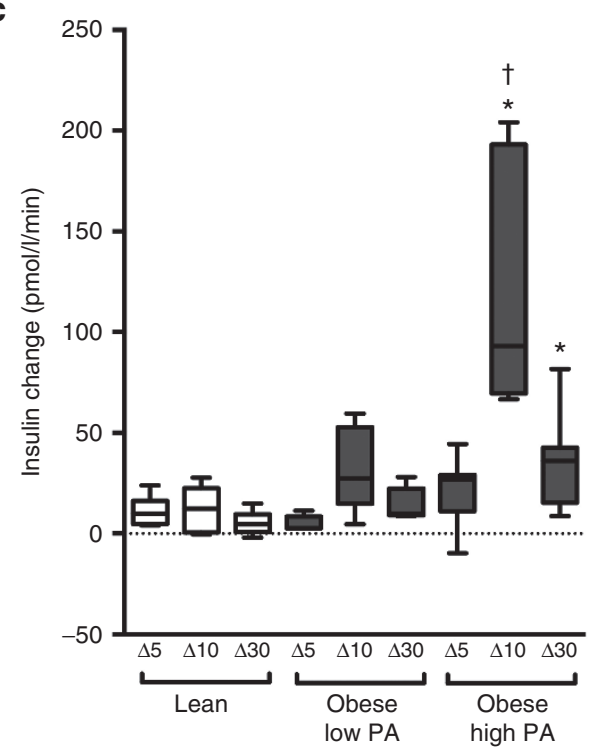

b

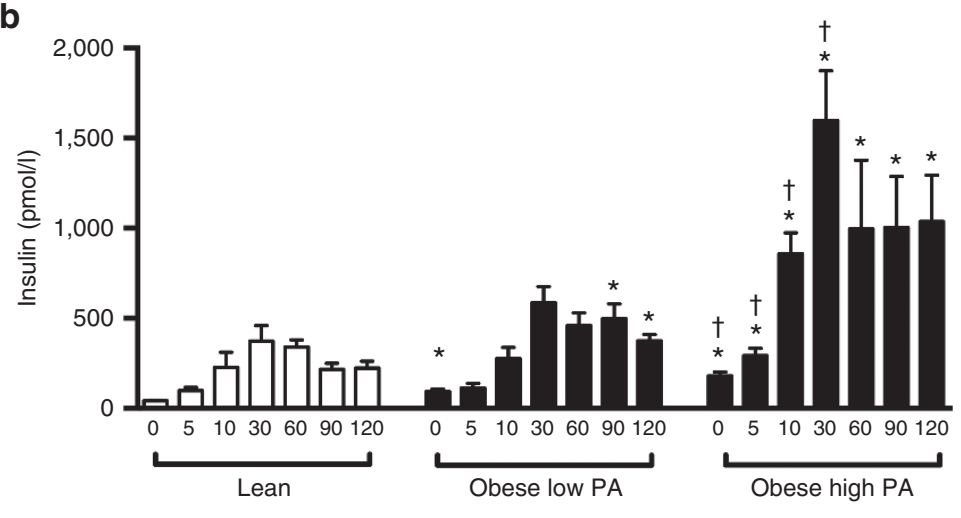

d

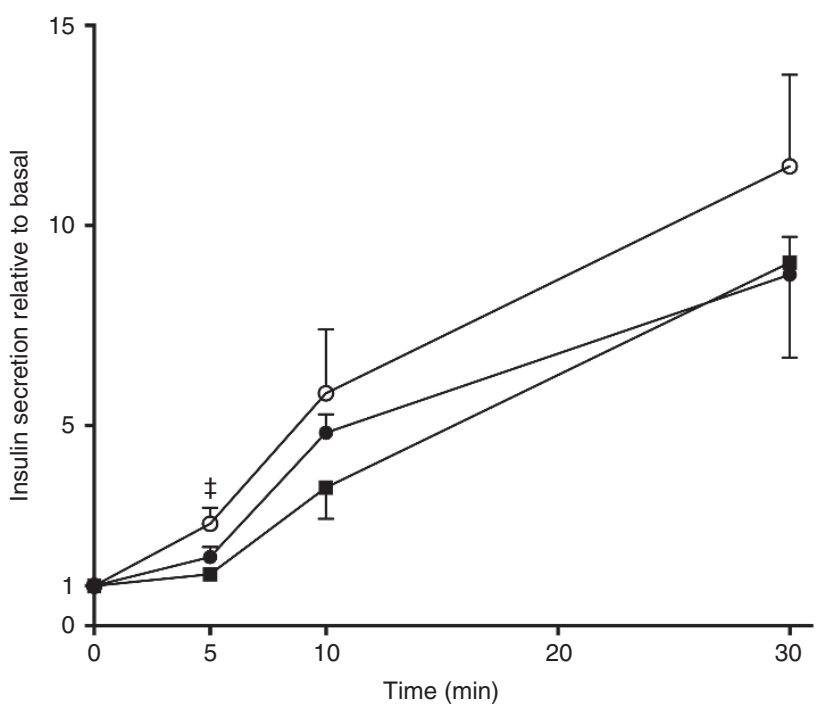

Figure 2. Insulin secretion in obese and lean children. Insulin levels during oral glucose tolerance test (OGTT) in obese children with high (black circles/ bars) or low (black squares/bars) palmitate levels and lean children (white circles/bars) are shown (panels $\mathbf{a}$ and $\mathbf{b}$ ). Changes in insulin concentration during first phase of insulin secretion (panel c) and insulin concentrations relative to basal concentrations during $30 \mathrm{~min}$ of OGTT (panel d) are shown. ${ }^{*} P<0.05$ obese vs. lean; ${ }^{\dagger} P<0.05$ obese with high palmitate vs. low palmitate. ${ }^{\ddagger} P<0.05$ lean vs. obese with low palmitate. Results are expressed as means \pm SEM for 5-10 obese and 10-21 lean subjects per time point.

concentration was after 30 min observed (Figure 2d). This was reduced to ninefold for obese children irrespective of palmitate levels. Obese children with low palmitate had a statistically lower initial fold increase compared with lean children (Figure 2d).

In obese adolescents, insulin concentrations during OGTT were attenuated and a delayed rise in insulin levels when challenged with glucose was observed (Figure 3a). The only difference in insulin levels between obese and lean adolescents was at fasting, however at $1 \mathrm{~h}$ obese children with high palmitate tended to have higher levels than lean children $(P=0.06)$ (Figure 3b). The lowest change in secretory rate was observed in obese adolescents with high palmitate between 0 and $5 \mathrm{~min}$, when levels rose with $2.6 \mathrm{pmol} / \mathrm{l} / \mathrm{min}$ on average, with a minvalue of $-4.4 \mathrm{pmol} / \mathrm{l} / \mathrm{min}$ (male, $14 \mathrm{y}$ old) (Figure $3 \mathrm{c}$ ). Indeed, in this group, $1 / 3$ showed negative change in insulin levels during this time period. In lean adolescents, a 12 -fold rise in insulin levels was observed (Figure 3d). In contrast, the obese adolescents showed merely a fivefold rise irrespective of palmitate levels, which was significantly lower than lean adolescents.
Area under the curve for insulin during the initial $30 \mathrm{~min}$ $\mathrm{AUC}_{30 \text { min }}$ as well as the insulinogenic index (IGI) was calculated to further examine the first-phase secretory response. In obese subjects with low palmitate levels, $\mathrm{AUC}_{30 \mathrm{~min}}$ was not different between children and adolescents. In contrast, in obese subjects with high palmitate levels, $\mathrm{AUC}_{30 \mathrm{~min}}$ was significantly higher in children compared with adolescents, lean children, and obese children with low palmitate (Figure 4a). Lean adolescents and obese adolescents with low palmitate levels showed higher IGI than children, respectively (Figure $4 \mathrm{~b}$ ). In contrast, the IGI was not different between children and adolescents with high palmitate, but children with high palmitate had higher IGI than lean children and obese children with low palmitate (Figure $4 \mathbf{b}$ ).

\section{Glucose-Stimulated Insulin Secretion From Isolated Human Islets Exposed to Palmitate}

Glucose-stimulated insulin secretion (GSIS) was measured from islets cultured in presence of palmitate for up to $7 \mathrm{~d}$ (Figure 5a). GSIS was almost doubled from islets cultured 


\section{Articles | staafetal.}

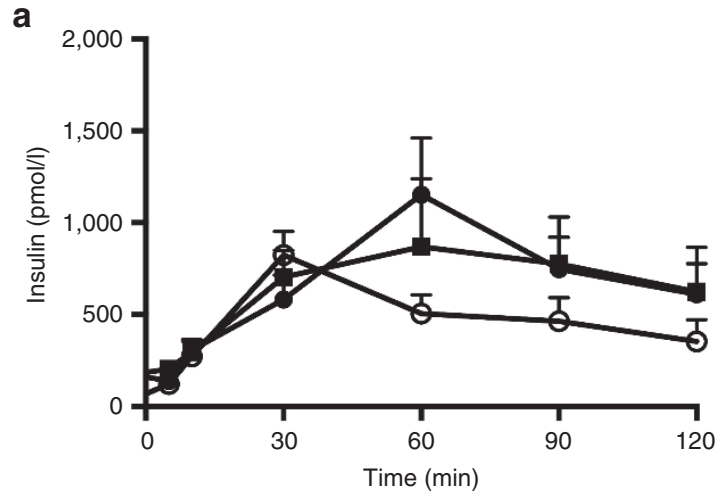

C

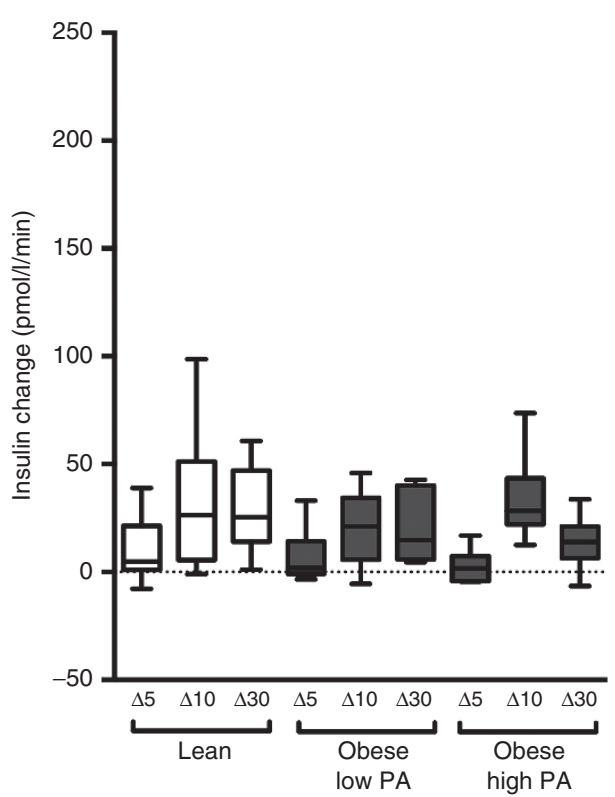

b

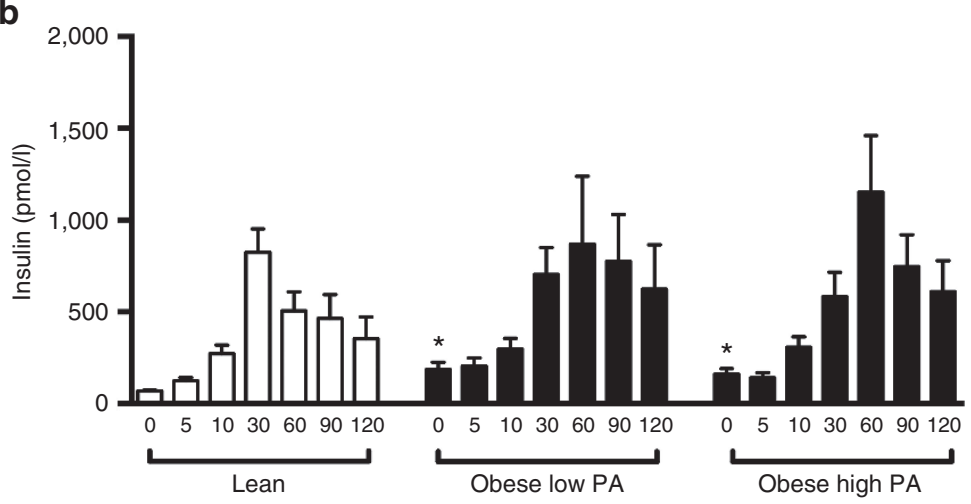

d

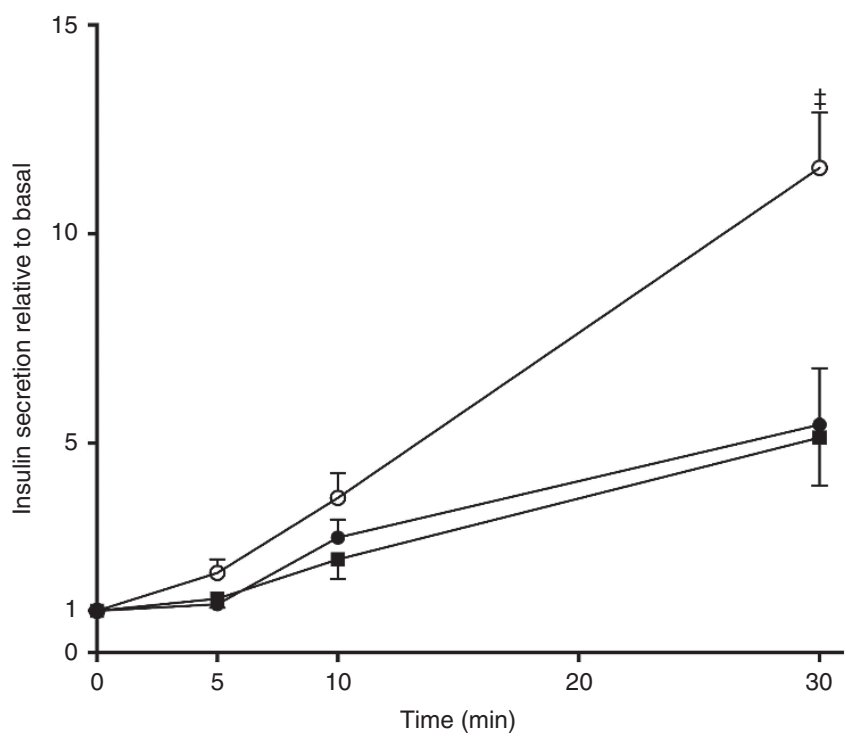

Figure 3. Insulin secretion in obese and lean adolescents. Insulin levels during oral glucose tolerance test (OGTT) in obese adolescents with high (black circles/bars) or low (black squares/bars) palmitate levels and lean adolescents (white circles/bars) are shown (panels a and b). Changes in insulin concentration during first phase of insulin secretion (panel c) and insulin concentrations relative to basal concentrations during 30 min of OGTT (panel d) are shown. ${ }^{*} P<0.05$ obese vs. lean; ${ }^{\ddagger} P<0.05$ lean vs. obese with low and high palmitate. Results are expressed as means \pm SEM for 5-10 obese and $10-21$ lean subjects per time point.

a

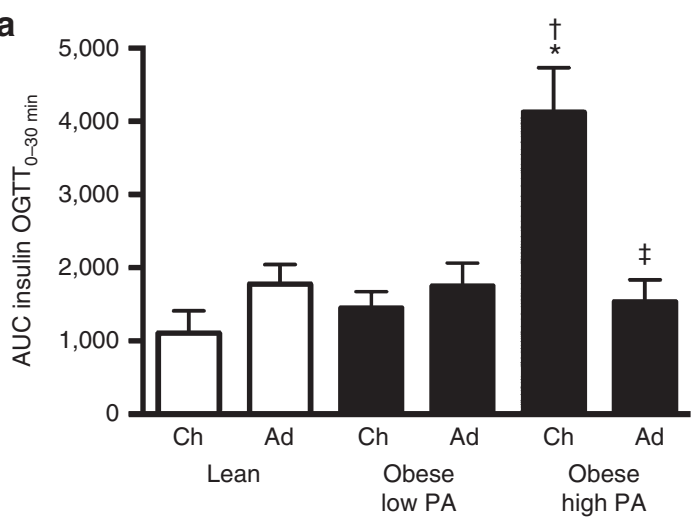

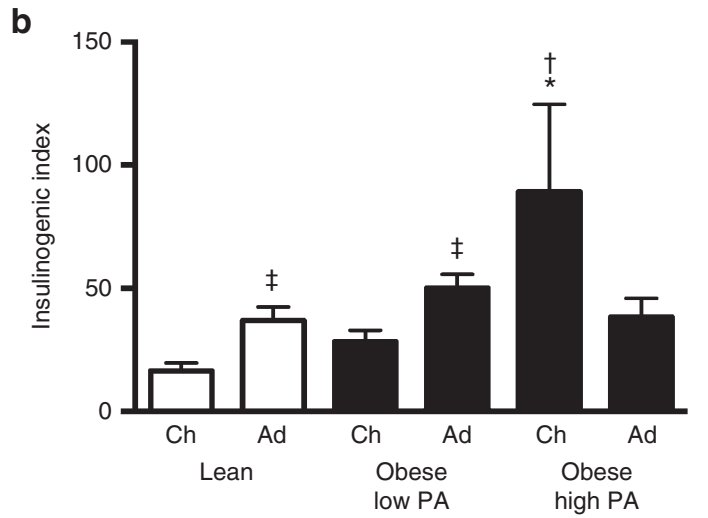

Figure 4. Insulin secretion indices. Insulin amounts during first $30 \mathrm{~min}$ of oral glucose tolerance test (OGTT), AUC $\mathrm{Cos}_{\text {min }}$ (panel a), and insulin amounts related to changes in glucose during the first $30 \mathrm{~min}$ of the OGTT, insulinogenic index (panel b) in lean children (Ch) and adolescents (Ad) (white bar) and obese children and adolescents (black bars) with high and low concentrations of palmitate (PA). Results are expressed as means \pm SEM. ${ }^{*} P<0.05$ obese vs. lean; ${ }^{+} P<0.05$ obese with high palmitate vs. low palmitate (within the same pubertal stage); ${ }^{\ddagger} P<0.05$ adolescents vs. children. 
in presence of palmitate for $2 \mathrm{~d}$ compared to control islets (Figure 5b). The increase was accounted for by increased insulin release during both the initial $10 \mathrm{~min}$ (first-phase) (Figure $5 \mathrm{c}$ ) and subsequent $10 \mathrm{~min}$ (second-phase) (Figure $5 \mathrm{~d}$ ) of insulin release in the presence of $20 \mathrm{mmol} / 1$ glucose. After $7 \mathrm{~d}$ of culture in the presence of palmitate, GSIS was significantly lower than after $2 \mathrm{~d}$ culture (Figure $5 \mathbf{b}$ ). The reduction in insulin secretion was paralleled by a reduction in both first and second phases of insulin secretion (Figure $5 c, d$ ).

\section{Insulin Content and Apoptosis in Isolated Human Islets Exposed} to Palmitate

Insulin content in islets exposed to elevated palmitate for $6 \mathrm{~h}$ and 2 $\mathrm{d}$ was similar to levels found in control islets (Figure 6a). Content was reduced to 50 and $30 \%$ of levels in control islets after 4 and $7 \mathrm{~d}$, respectively. Cleaved caspase 3 content was not different in islets cultured for 2 or $4 \mathrm{~d}$ in presence of palmitate. The apoptotic marker was approximately 50\% higher after $7 \mathrm{~d}$ (Figure 6b).

\section{DISCUSSION}

This study was designed to explore the association between palmitate and insulin secretion, using both in vivo cohort and in vitro models. We found that children and adolescents with obesity had on average $20 \%$ higher palmitate levels than lean subjects and that a time of exposure-dependent relationship between palmitate and insulin secretion exists in vitro. Previous studies have reported that circulating NEFAs are elevated in obesity and T2DM (5), while others have questioned
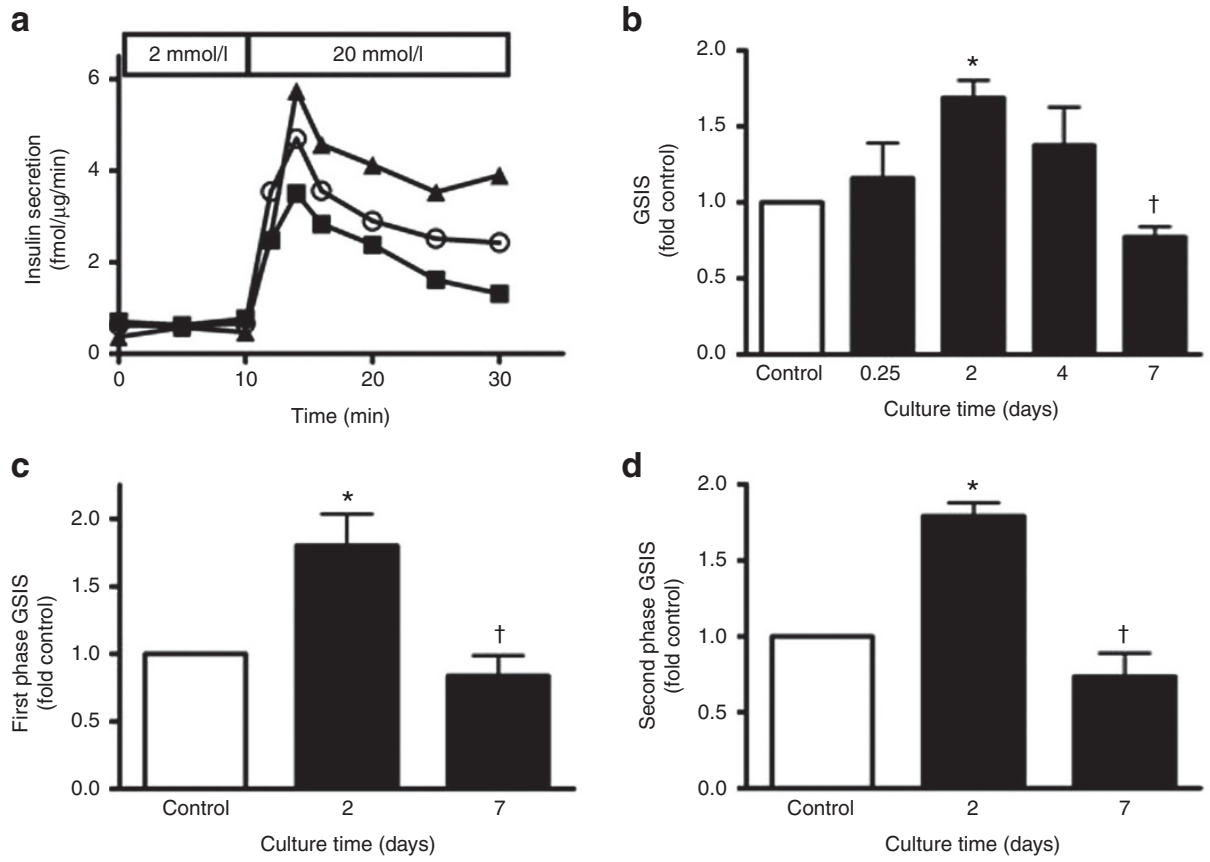

Figure 5. Insulin secretion after palmitate treatment in vitro. Glucose-stimulated insulin secretion from isolated human islets cultured in the presence of palmitate for 0 (open circles), 2 (closed triangles), or 7 (closed squares) days (panel a). After culture, islets were perifused in the presence of 2 and 20 $\mathrm{mmol} / \mathrm{l}$ glucose as indicated. Insulin released during $20 \mathrm{~min}$ (panel b), first $10 \mathrm{~min}$ (panel c) and last $10 \mathrm{~min}$ (panel d) at $20 \mathrm{mmol} / \mathrm{l}$ glucose in absence (white bar) or presence (black bars) of palmitate for the indicated culture time periods are shown. Representative of four to eight independent experiments (panel a). Results are expressed as means \pm SEM. ${ }^{*} P<0.05$ vs. control; ${ }^{\dagger} P<0.05$ vs. 2 days culture.

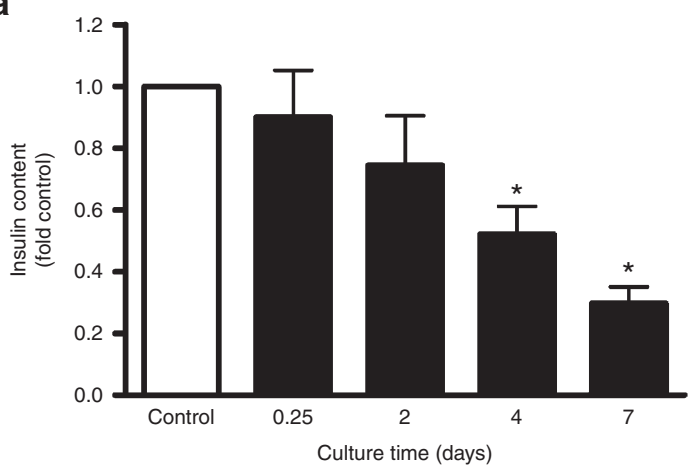

b

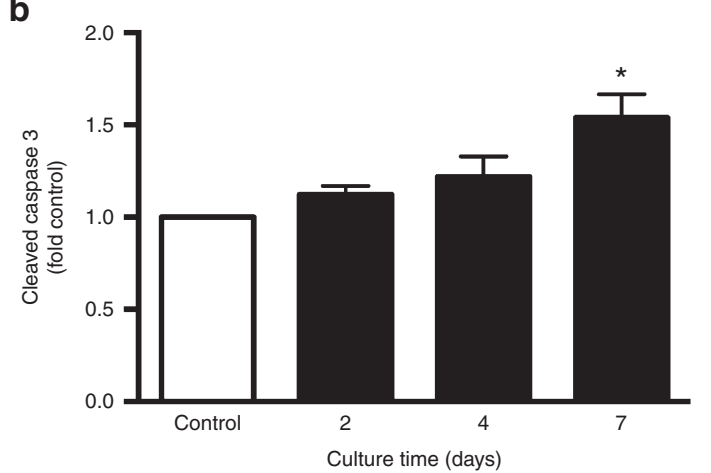

Figure 6. Insulin content and apoptosis after palmitate treatment in vitro. Insulin content (panel a) and cleaved caspase 3 (panel b) in isolated human islets exposed to $0.5 \mathrm{mmol} / \mathrm{l}$ palmitate for 0 (open bar), $0.25,2,4$, or 7 (closed bars) days are shown. Results are expressed as means \pm SEM for four independent experiments. ${ }^{*} P<0.05$ vs. control. 


\section{Articles | Staafet al.}

the association between NEFAs and adiposity $(23,24)$. Elevated NEFAs impair insulin secretion, generally referred to as lipotoxicity (25), which is partly influenced by dietary habits (11). Palmitate is one of the most abundant circulating NEFAs (10) and has been associated with changes in $\beta$-cell function both in vivo $(11,26)$ and in vitro $(13-17,19,22)$ but previously not related to hyperinsulinemia in children with obesity. In this study, we found a relationship between fasting palmitate and insulin levels in obese children and adolescents. Such relationship does not seem to be present in lean subjects, suggesting that additional mechanisms contribute in regulating insulin secretion when palmitate levels are within normal range.

The most accentuated rise in insulin secretory rate in response to glucose, as well as the highest insulin levels, was observed in obese children with high palmitate levels. The kinetics of the insulin curve were similar to lean subjects, however, with a distinct peak after $30 \mathrm{~min}$, indicating that these subjects still have a normal first-phase insulin response and are not at immediate risk of developing T2DM (27). In addition, obese children with high palmitate had the highest IGI, suggesting a heightened sensitivity to glucose during the initial $30 \mathrm{~min}$, which supports the previous report of increased IGI in subjects with relatively high amounts of palmitate in the diet (11). Another aspect of the high insulin secretory response is its potential role as an early factor in development of obesity. In a genetically modified mouse-model, where the insulin response was about $50 \%$ of wild-type mice, no weight gain upon feeding with high-caloric diet was observed (28). It appeared that extra caloric intake was dissipated as heat in adipose tissue, which expressed elevated levels of proteins involved in uncoupling.

In parallel, isolated islets of Langerhans were after $2 \mathrm{~d}$ responding to elevated palmitate levels with accentuated insulin secretion. The observation of hyperinsulinemia in obese children with high palmitate levels in combination with the in vitro findings suggests that high palmitate levels may accentuate the $\beta$-cell response to glucose in children. This might be due to both enhanced metabolism and mitochondrial respiration $(29,30)$. Causality needs to be further elucidated in vivo by mechanistic experiments, however, since saturated fatty acids also have been connected to insulin resistance $(31,32)$.

In obese adolescents with high palmitate, insulin levels were not elevated during the initial $30 \mathrm{~min}$. Instead, a delayed insulin peak at $60 \mathrm{~min}$ was observed, which has been connected with impending glucose intolerance and is a risk factor of T2DM in adults (33). Indeed, during the initial 5 min of the OGTT, the lowest secretory rate was observed in obese adolescents with high palmitate levels. Interestingly, $1 / 3$ of subjects in this group showed an initial decline in insulin concentrations. This paradoxical secretory response to glucose has been attributed reduced ability of $\beta$-cells to efficiently metabolize and increase the ATP/ADP ratio, leading to delay in closure of ATP-dependent $\mathrm{K}^{+}$-channels and $\mathrm{Ca}^{2+}$ influx via voltagedependent L-type channels (34).

In islets exposed to chronically high palmitate levels, insulin hypersecretion was followed by impaired insulin secretion. Interestingly, a decline in insulin content preceded the impairment in insulin secretion. We propose that the reduced insulin secretion is partially a result of decline in insulin content $(16,22)$, which may reflect inability of insulin biosynthesis (35) and impaired formation of insulin granules (36) to maintain adequate $\beta$-cell granulation in phase of prolonged elevated insulin release. In addition, the exocytosis machinery is affected by chronic palmitate treatment, contributing to reduce secretion $(16,37)$. In the current study, after $7 \mathrm{~d}$ of palmitate treatment, apoptosis was significantly increased, which is in agreement with previous work $(12,15,16,22)$. Palmitate may induce apoptosis by generation of intracellular ceramide and increasing reactive oxygen species $(12,15,38)$. In summary, the aforementioned may be potential underlying mechanisms for the lowered secretory response observed in obese adolescents with high palmitate levels.

We acknowledge the difficulties in translating the in vivo and in vitro results of this study and several aspects limit the possibilities to draw conclusions. They include the relatively small study population with no longitudinal analyses available. In addition, palmitate levels may vary over time in subjects depending on dietary habit (39). Furthermore, there are additional NEFAs, amino acids and hormones like glucagonlike peptide- 1 and gastric inhibitory peptide in the circulation, which influence insulin secretion. Moreover palmitate was not measured during the OGTT. Since NEFA levels are expected to decline during an OGTT as insulin levels rise (8), it can be assumed that high fasting palmitate levels have a direct influence on insulin secretion mainly during the first phase insulin response, but this needs to be validated.

In conclusion, we propose based on evidence from in vivo and in vitro studies that hyperinsulinemia observed in obese children with elevated fasting palmitate levels may reflect accentuated insulin secretion, and similarly that delayed insulin response in obese adolescents with high palmitate may implicate a declining $\beta$-cell function. If these interpretations are correct, for which additional work is required, high fasting palmitate levels could be connected with increased risk of developing T2DM.

\section{METHODS}

\section{Study Population}

Eighty children and adolescents were included in the cross-sectional study; 40 subjects with obesity (age and gender adjusted BMI $\geq 30$ ) and 40 lean $(\mathrm{BMI}<25)$ subjects. Subjects were $3-18$ y old, with approximately the same number of males and females. All subjects had normal fasting glucose levels (Table 1) and were part of the Uppsala Longitudinal Study of Childhood Obesity cohort (40). Prepubertal and pubertal subjects are referred to as "children" and "adolescents", respectively. The Regional ethical committee in Uppsala approved the study (2010/036 and 2012/318). Subject and parental informed consent have been obtained.

\section{Blood Sampling and Measurements}

Blood was sampled as previously described (40). In short, blood was drawn from a peripheral vein using a stationary catheter. After sampling, ethylenediaminetetraacetic acid-tubes used for palmitate analyses were centrifuged at $4{ }^{\circ} \mathrm{C}$ and plasma stored at $-72^{\circ} \mathrm{C}$. Analysis of glucose (Abbott Architect, Abbott Diagnostics, Lake Forest, Ill), insulin (Cobas E602, Roche Diagnostics, Indianapolis, IN), follicle-stimulating hormone, and luteinizing hormone (Cobas E601, Roche Diagnostics, Indianapolis, IN) (subjects with follicle-stimulating hormone $>2 \mathrm{IU} / \mathrm{l}$ and/or luteinizing hormone $>0.6 \mathrm{IE} / \mathrm{l}$ were considered pubertal) were conducted at the Uppsala University Hospital laboratory in accordance 
with local standard operating procedures. Blood samples with hemolysis were omitted with regard to insulin analyses.

\section{Palmitate Measurements}

Circulating levels of palmitate were quantified in plasma samples as previously described (10). In brief, frozen plasma samples were thawed and mixed with internal standard (heptanoic acid, C17:0). Thereafter, lipids were extracted and derivatized by amidation. Finally, amide derivatives were analyzed using gas-chromatography mass spectrometry (TQ-GC-MS/MS; Bruker Daltonics Inc., Billerica, MA, USA). Identification was done by comparing mass spectra of standard samples of amides of fatty acids with study samples.

\section{Oral Glucose Tolerance Test}

OGTT was conducted as previously described (40). In brief, after drinking a glucose solution ( $1.75 \mathrm{~g}$ glucose per kilogram body mass, maximum $75 \mathrm{~g}$ ), blood samples were collected after 5, 10, 30, 60, 90, and $120 \mathrm{~min}$. Some subjects were unable to complete the OGTT.

\section{Human Islet Isolation and Culture}

Human islets, with a purity of at least $60 \%$, were isolated from deceased adult donors. Nondiabetic female and male donors, age 40-65, were included in the study. Culture was conducted in CMRL 1066 medium (Invitrogen, Paisley, UK) containing 10\% fetal bovine serum (Invitrogen), $1 \%$ Penicillin-Streptomycin, and $1 \%$ Glutamine (Invitrogen) at $37{ }^{\circ} \mathrm{C}$ and $5 \% \mathrm{CO}_{2}$. Palmitate (Sigma Aldrich, St. Louis, MO) was prepared as previously described (22) to a final concentration of $0.5 \mathrm{mmol} / \mathrm{l}$ with $0.5 \%$ BSA (Roche Diagnostics, Mannheim, Germany) and added to the culture medium. Culture duration was set to 0 (control), $0.25,2$, 4 , or $7 \mathrm{~d}$. Ethical approval for all procedures involving human islets was obtained from the regional ethical board in Uppsala (2010/006).

\section{GSIS}

After culture, viable islets were selected and perifused with Krebs-Ringer bicarbonate HEPES-buffer containing $2 \mathrm{mmol} / \mathrm{l}$ glucose for $60 \mathrm{~min}$ as previously described (22). Subsequently, the glucose concentration was raised to $20 \mathrm{mmol} / \mathrm{l}$ and perifusion was continued for another $20 \mathrm{~min}$ and perifusate collected after 2, 4, 6, 10, 15, and $20 \mathrm{~min}$. First-phase insulin secretion was defined as the initial $10 \mathrm{~min}$ after increasing the glucose concentration to $20 \mathrm{mmol} / \mathrm{l}$, while the subsequent $10 \mathrm{~min}$ were defined as second-phase insulin secretion. Quantification of insulin in the samples obtained from islet perifusions was done by enzyme-linked immunosorbent assay as previously described (22) and insulin section was normalized to total protein measured by Lowry.

\section{Insulin Content and Apoptosis Measurements}

After culture, islets were placed in cold lysis-buffer (1\% Triton and $0.1 \%$ protease inhibitory cocktail in phosphate buffer solution) and incubated on shaker for $60 \mathrm{~min}$. Islets were thereafter sonicated on ice. Insulin content was quantified by enzyme-linked immunosorbent assay as previously described (22). Cleaved caspase 3 (Cell Signaling, Danvers, MA) was measured as a marker of apoptosis and quantified by western blot. Immunoreactive bands were visualized by chemiluminescence using the ChemiDoc XRS+ system (BioRad, Hercules, $\mathrm{CA})$ and quantified with Quantity One (BioRad). $\beta$-actin (Cell Signaling) was used for normalization.

\section{Calculations and Statistical Analyses}

Data was screened for normal distribution with the D'Agostino \& Pearson omnibus normality test. ANOVA was used to compare groups followed by a post hoc test (Mann-Whitney's and Bonferroni's tests). The insulin secretory rate; change in concentrations between the different OGTT-time points per minutes, was calculated. Postprandial insulin secretion has previously been investigated by IGI and AUC (11). The trapezium rule was used to calculate insulin $\mathrm{AUC}_{30 \text { min, }}$, while IGI was calculated using the formula Insulin ${ }_{(30 \mathrm{~min}-0 \mathrm{~min})} / \mathrm{Glucose}_{(30 \mathrm{~min}-0 \mathrm{~min})^{\prime}}$ Group statistics are presented as mean \pm SEM. Statistical analyses were conducted using GraphPad Prism 6.0c (GraphPad Software, La Jolla, CA). Statistical significance was set to $P<0.05$.

\section{ACKNOWLEDGMENTS}

We thank the children and their families for participating in the study. We also acknowledge the Nordic Network for Clinical Islet Transplantation, supported by the Swedish national strategic research initiative
EXODIAB (Excellence of Diabetes Research in Sweden) and the Juvenile Diabetes Research Foundation (JDRF) for supply of human islets (JDRF Award 31-2008-413 and the European Consortium for Islet Transplantation for Basic Research Program.

\section{STATEMENT OF FINANCIAL SUPPORT}

This study was supported by European Commission FP7 project Beta-Judo (grant number 279153), Swedish Diabetes Association (grant number DIA 2013-043), Swedish Medical Research Council (72X-14019), Uppsala Regional Research Council, Uppsala University Innovation, Gillbergska Foundation, Family Ernfors Foundation (grant number 150430) and SRC 621-2011-4423, 2015-4870.

\section{Disclosure: None to disclose.}

\section{REFERENCES}

1. Van Name M, Santoro N. Type 2 diabetes mellitus in pediatrics: a new challenge. World J Pediatr 2013;9:293-9.

2. Giannini C, Caprio S. Islet function in obese adolescents. Diabetes Obes Metab 2012;14 Suppl 3:40-5.

3. Matyka KA. Type 2 diabetes in childhood: epidemiological and clinical aspects. Br Med Bull 2008;86:59-75.

4. Dea TL. Pediatric obesity \& type 2 diabetes. MCN Am J Matern Child Nurs 2011;36:42-8.

5. Arner P, Rydén M. Fatty acids, obesity and insulin resistance. Obes Facts 2015;8:147-55.

6. Boden G. Obesity and free fatty acids. Endocrinol Metab Clin North Am 2008;37:635-46, viii-ix.

7. Sabin MA, De Hora M, Holly JM, et al. Fasting nonesterified fatty acid profiles in childhood and their relationship with adiposity, insulin sensitivity, and lipid levels. Pediatrics 2007;120:e1426-33.

8. Rebelos E, Seghieri M, Natali A, et al. Influence of endogenous NEFA on beta cell function in humans. Diabetologia 2015;58:2344-51.

9. Broussard JL, Kolka CM, Castro AV, et al. Elevated nocturnal NEFA are an early signal for hyperinsulinaemic compensation during diet-induced insulin resistance in dogs. Diabetologia 2015;58:2663-70.

10. Ubhayasekera SJ, Staaf J, Forslund A, Bergsten P, Bergquist J. Free fatty acid determination in plasma by GC-MS after conversion to Weinreb amides. Anal Bioanal Chem 2013;405:1929-35.

11. Bermudez B, Ortega-Gomez A, Varela LM, et al. Clustering effects on postprandial insulin secretion and sensitivity in response to meals with different fatty acid compositions. Food Funct 2014;5:1374-80.

12. Maris M, Robert S, Waelkens E, et al. Role of the saturated nonesterified fatty acid palmitate in beta cell dysfunction. J Proteome Res 2013;12: $347-62$.

13. Gwiazda KS, Yang TL, Lin Y, Johnson JD. Effects of palmitate on ER and cytosolic Ca2+ homeostasis in beta-cells. Am J Physiol Endocrinol Metab 2009;296:E690-701.

14. Sargsyan E, Ortsäter H, Thorn K, Bergsten P. Diazoxide-induced beta-cell rest reduces endoplasmic reticulum stress in lipotoxic beta-cells. J Endocrinol 2008;199:41-50.

15. Manukyan L, Ubhayasekera SJ, Bergquist J, Sargsyan E, Bergsten P. Palmitate-induced impairments of $\beta$-cell function are linked with generation of specific ceramide species via acylation of sphingosine. Endocrinology 2015;156:802-12.

16. Vasu S, McClenaghan NH, McCluskey JT, Flatt PR. Effects of lipotoxicity on a novel insulin-secreting human pancreatic $\beta$-cell line, 1.1B4. Biol Chem 2013;394:909-18.

17. Sato Y, Fujimoto S, Mukai E, et al. Palmitate induces reactive oxygen species production and $\beta$-cell dysfunction by activating nicotinamide adenine dinucleotide phosphate oxidase through Src signaling. J Diabetes Investig 2014;5:19-26.

18. Diakogiannaki E, Welters HJ, Morgan NG. Differential regulation of the endoplasmic reticulum stress response in pancreatic beta-cells exposed to long-chain saturated and monounsaturated fatty acids. J Endocrinol 2008; 197:553-63.

19. Jeffrey KD, Alejandro EU, Luciani DS, et al. Carboxypeptidase E mediates palmitate-induced beta-cell ER stress and apoptosis. Proc Natl Acad Sci USA 2008;105:8452-7. 


\section{Articles | Staafet al.}

20. Haber EP, Procópio J, Carvalho CR, Carpinelli AR, Newsholme P, Curi R. New insights into fatty acid modulation of pancreatic beta-cell function. Int Rev Cytol 2006;248:1-41.

21. Gravena C, Mathias PC, Ashcroft SJ. Acute effects of fatty acids on insulin secretion from rat and human islets of Langerhans. J Endocrinol 2002;173:73-80.

22. Kristinsson H, Smith DM, Bergsten P, Sargsyan E. FFAR1 is involved in both the acute and chronic effects of palmitate on insulin secretion. Endocrinology 2013;154:4078-88.

23. Karpe F, Dickmann JR, Frayn KN. Fatty acids, obesity, and insulin resistance: time for a reevaluation. Diabetes 2011;60:2441-9.

24. Ferrannini E, Camastra S, Coppack SW, Fliser D, Golay A, Mitrakou A. Insulin action and non-esterified fatty acids. The European Group for the Study of Insulin Resistance (EGIR). Proc Nutr Soc 1997;56:753-61.

25. Unger RH. Lipotoxicity in the pathogenesis of obesity-dependent NIDDM. Genetic and clinical implications. Diabetes 1995;44:863-70.

26. Malin SK, Kashyap SR, Hammel J, Miyazaki Y, DeFronzo RA, Kirwan JP. Adjusting glucose-stimulated insulin secretion for adipose insulin resistance: an index of $\beta$-cell function in obese adults. Diabetes Care 2014;37:2940-6.

27. Takahara M, Katakami N, Matsuoka TA, Noguchi M, Shimomura I. An inverse U-shaped association of late and peak insulin levels during an oral glucose load with glucose intolerance in a Japanese population: a crosssectional study. Endocr J 2015;62:217-26.

28. Mehran AE, Templeman NM, Brigidi GS, et al. Hyperinsulinemia drives diet-induced obesity independently of brain insulin production. Cell Metab 2012;16:723-37.

29. Ostenson CG, Chen J, Sheu L, Gaisano HY. Effects of palmitate on insulin secretion and exocytotic proteins in islets of diabetic Goto-Kakizaki rats. Pancreas 2007;34:359-63.

30. Kristinsson H, Bergsten P, Sargsyan E. Free fatty acid receptor 1 (FFAR1/ GPR40) signaling affects insulin secretion by enhancing mitochon- drial respiration during palmitate exposure. Biochim Biophys Acta 2015;1853:3248-57.

31. Yuzefovych L, Wilson G, Rachek L. Different effects of oleate vs. palmitate on mitochondrial function, apoptosis, and insulin signaling in L6 skeletal muscle cells: role of oxidative stress. Am J Physiol Endocrinol Metab 2010;299:E1096-105.

32. Gu N, Guo Q, Mao K, et al. Palmitate increases musclin gene expression through activation of PERK signaling pathway in $\mathrm{C} 2 \mathrm{C} 12$ myotubes. Biochem Biophys Res Commun 2015;467:521-6.

33. Hayashi T, Boyko EJ, Sato KK, et al. Patterns of insulin concentration during the OGTT predict the risk of type 2 diabetes in Japanese Americans. Diabetes Care 2013;36:1229-35.

34. Bergsten P, Hellman B. Glucose inhibits insulin release when not promoting the entry of calcium into the beta-cells. Biochem Biophys Res Commun 1984;125:875-81.

35. Vernier S, Chiu A, Schober J, et al. $\beta$-cell metabolic alterations under chronic nutrient overload in rat and human islets. Islets 2012;4:379-92.

36. Sol ER, Hovsepyan M, Bergsten P. Proteins altered by elevated levels of palmitate or glucose implicated in impaired glucose-stimulated insulin secretion. Proteome Sci 2009;7:24.

37. Hoppa MB, Collins S, Ramracheya R, et al. Chronic palmitate exposure inhibits insulin secretion by dissociation of $\mathrm{Ca}(2+)$ channels from secretory granules. Cell Metab 2009;10:455-65.

38. Listenberger LL, Ory DS, Schaffer JE. Palmitate-induced apoptosis can occur through a ceramide-independent pathway. J Biol Chem 2001;276:14890-5.

39. Scaglioni S, Veduci E, Agostoni C, et al. Dietary habits and plasma fatty acids levels in a population of Italian children: is there any relationship? Prostaglandins Leukot Essent Fatty Acids 2004;71:91-5.

40. Forslund A, Staaf J, Kullberg J, Ciba I, Dahlbom M, Bergsten P. Uppsala Longitudinal Study of Childhood Obesity: protocol description. Pediatrics 2014;133:e386-93. 